\title{
Inferior Internal Articular Artery
}

National Cancer Institute

\section{Source}

National Cancer Institute. Inferior Internal Articular Artery. NCI Thesaurus. Code C32778.

A blood vessel arising from the popliteal artery that supplies blood to the head of the tibia and the knee joint. 